\title{
Bimodal Visualization of Endogenous Nitric Oxide in Lysosomes with A Two-Photon Iridium(III) Phosphorescent Probe
}

\author{
Weijun Wu,${ }^{\dagger}$ Ruilin Guan,${ }^{\dagger}$ Xinxing Liao, ${ }^{\dagger}$ Xu Yan,${ }^{\dagger}$ Thomas W. Rees, ${ }^{\dagger}$ Liangnian \\ $\mathrm{Ji}^{\dagger}{ }^{\dagger}$ and Hui Chao ${ }^{*}, \dagger,+$ \\ ${ }^{\dagger}$ MOE Key Laboratory of Bioinorganic and Synthetic Chemistry, School of Chemistry, Sun \\ Yat-Sen University, Guangzhou 510275, P. R. China. \\ E-mail: ceschh@mail.sysu.edu.cn; Fax:+86-20-84112245; Tel: +86-20-84110613 \\ $\star$ MOE Key Laboratory of Theoretical Organic Chemistry and Functional Molecule, School \\ of Chemistry and Chemical Engineering, Hunan University of Science and Technology, \\ Xiangtan, 400201, P. R. China.
}

\section{Content}

Experimental section

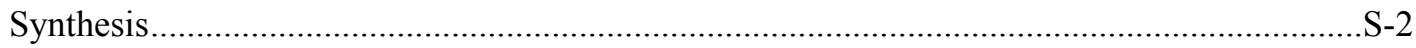

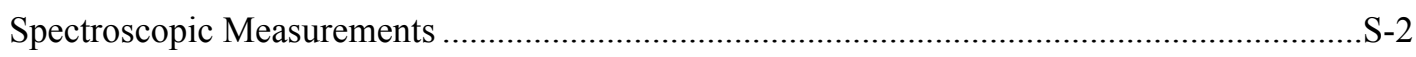

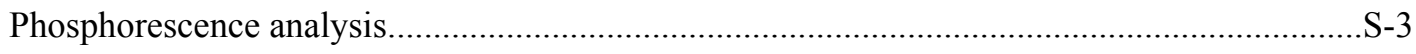

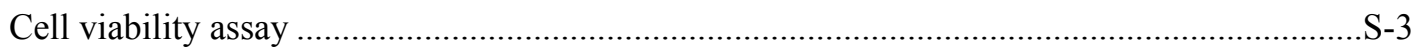

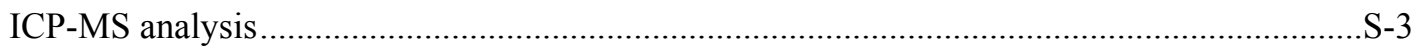

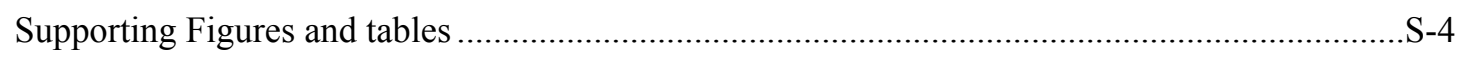

Figure S1. ESI-MS and ${ }^{1} \mathrm{H}$ NMR spectrum of compound 1 1 . ................................................

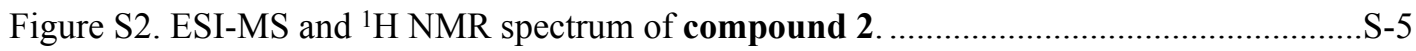

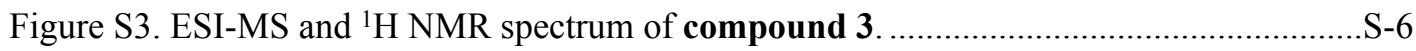

Figure S4. ESI-MS and ${ }^{1} \mathrm{H}$ NMR spectrum of Ir-BPDA....................................................

Figure S5. ESI-MS and ${ }^{1} \mathrm{H}$ NMR spectrum of Ir-PDA ...................................................... S-8

Figure S6. ESI-MS spectrum of the product of Ir-BPDA reacted with NO ............................. S-9

Figure S7. Absorption plot and phosphorescent spectra of Ir-BPDA before and after addition of

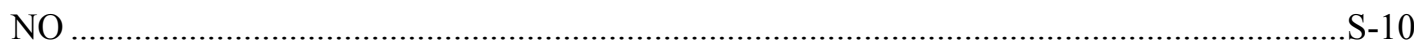

Figure S8. Plots of emission intensity of Ir-BPDA and Ir-BPDA after addition of NO ........S-10

Figure S9. Emission spectra of Ir-PDA after addition of NO .......................................... S-11

Figure S10. Phosphorescence lifetime of Ir-BPDA and Ir-PDA under different $\mathrm{pH}$ values in the

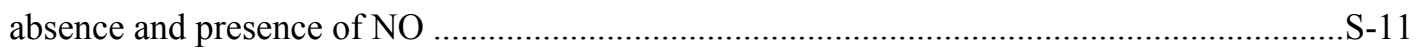

Figure S11. Viabilities of RAW 264.7 cells incubated with Ir-BPDA …………….............. -12

Figure S12. ICP-MS data of RAW 264.7 cells incubated with Ir-BPDA ................................ -12

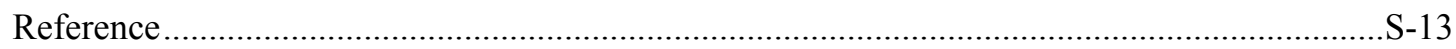




\section{Experimental section}

\section{Synthesis}

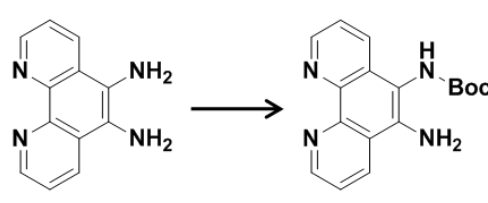

1

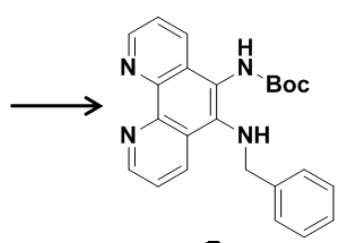

2

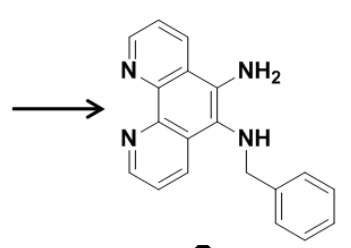

3

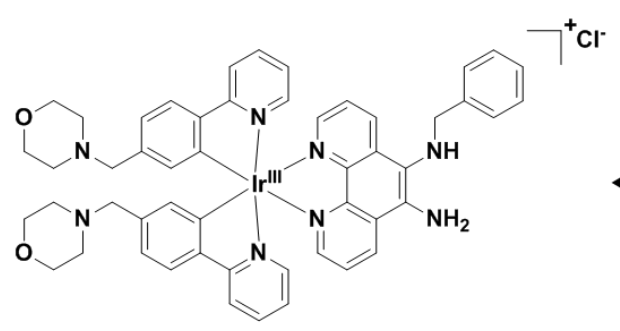

Ir-BPDA

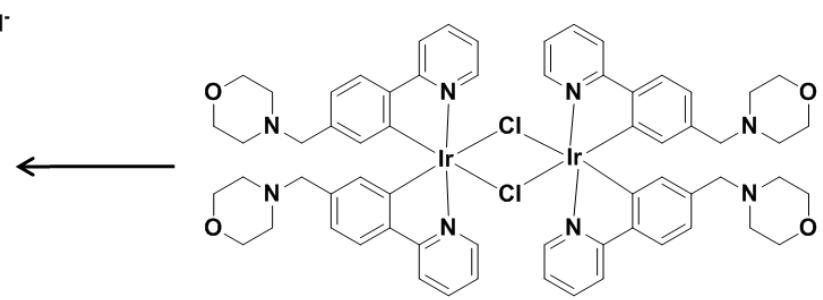

$\left[\operatorname{lr}(\mathrm{pbm})_{2} \mathrm{Cl}\right]_{2}$

\section{Spectroscopic Measurements}

Nitric oxide (NO) stock solution was prepared by purging PBS $\left(0.01 \mathrm{M}, \mathrm{pH}\right.$ 7.4) with $\mathrm{N}_{2}$ gas for $30 \mathrm{~min}$ and then with DEA-NONOate for $30 \mathrm{~min}$ at $25^{\circ} \mathrm{C}$. Other ROS and RNS were prepared as listed below. ${ }^{1}$

(1) ClO- : It was prepared by dilution of commercial $\mathrm{NaClO}$ solution in deionized water and the concentration of the $\mathrm{ClO}^{-}$stock solution was determined by measuring the absorbance at $209 \mathrm{~nm}$ with a molar extinction coefficient of $350 \mathrm{M}^{-1} \mathrm{~cm}^{-1}$.

(2) $\mathrm{H}_{2} \mathrm{O}_{2}$ : Commercial $\mathrm{H}_{2} \mathrm{O}_{2}$ was used as $\mathrm{H}_{2} \mathrm{O}_{2}$ source. The concentration of the $\mathrm{H}_{2} \mathrm{O}_{2}$ stock solution was determined by measuring the absorbance at $240 \mathrm{~nm}$ with a molar extinction coefficient of $43.6 \mathrm{M}^{-1} \mathrm{~cm}^{-1}$.

(3) $\bullet \mathrm{OH}$ : It was generated in the Fenton system from ferrous ammonium sulfate and hydrogen peroxide. To a solution of $\mathrm{H}_{2} \mathrm{O}_{2}(1.0 \mathrm{mM}, 1.0 \mathrm{~mL})$ in $\mathrm{PBS}(10 \mathrm{mM}, \mathrm{pH} 7.4)$ was added $\mathrm{FeSO}_{4}$ solution $(1.0 \mathrm{mM}, 100 \mu \mathrm{L})$ at ambient temperature (stock solution $0.1 \mathrm{mM}$ ).

(4) $\mathrm{O}_{2} \bullet^{\bullet}$ : Solid potassium superoxide was dissolved in dry DMSO to make a superoxide radical anion solution $(0.1 \mathrm{mM})$.

(5) $\mathrm{NO}_{2}^{-}: \mathrm{NaNO}_{2}$ was dissolved in deionized water to make a $\mathrm{NO}_{2}{ }^{-}$stock solution $(1 \mathrm{mM})$.

(6) $\mathrm{OONO}^{-}$: To a vigorously stirred solution of $\mathrm{NaNO}_{2}(0.6 \mathrm{M}, 10 \mathrm{~mL})$ and $\mathrm{H}_{2} \mathrm{O}_{2}(0.7 \mathrm{M}, 10 \mathrm{~mL})$ in deionized $\mathrm{H}_{2} \mathrm{O}$ at $0{ }^{\circ} \mathrm{C}$ was added $\mathrm{HCl}(0.6 \mathrm{M}, 10 \mathrm{~mL})$, followed by the rapid addition of $\mathrm{NaOH}$ solution $(1.5 \mathrm{M}, 20 \mathrm{~mL})$. Excess hydrogen peroxide was removed by passing the solution through a short column of $\mathrm{MnO}_{2}$. The concentration of $\mathrm{ONOO}^{-}$was determined by UV analysis with the extinction coefficient at $302 \mathrm{~nm}\left(\varepsilon=1670 \mathrm{M}^{-1} \mathrm{~cm}^{-1}\right)$ according to $\mathrm{c}=\mathrm{A} /(\mathrm{b} \varepsilon)$. Aliquots of the solution were stored at $-20{ }^{\circ} \mathrm{C}$ for use.

(7) $\mathrm{NO}_{3}{ }^{-}: \mathrm{NaNO}_{3}$ was dissolved in deionized water to make a $\mathrm{NO}_{3}{ }^{-}$stock solution $(1 \mathrm{mM})$.

(8) other ions: $\mathrm{NaCl}, \mathrm{MgCl}_{2}, \mathrm{KCl}, \mathrm{CaCl}_{2}, \mathrm{FeCl}_{2}, \mathrm{FeCl}_{3}, \mathrm{CuCl}, \mathrm{CuCl}_{2}, \mathrm{ZnCl}_{2}$ and $\mathrm{AlCl}_{3}$ were 
dissolved in deionized water to make the corresponding ions stock solution $(1 \mathrm{mM})$.

\section{Phosphorescence analysis}

Ir-BPDA was diluted to $10 \mu \mathrm{M}$ in PBS buffer/DMSO (90:10 v/v), and the appropriate analytes were added. The emission spectra were measured after a 10 min reaction with standard $1.0 \mathrm{~cm}$ quartz cells. The excitation was set at $405 \mathrm{~nm}$ in the emission spectra. Quantum yields of the phosphorescence were calculated according to the reference at room temperature and $\left[\mathrm{Ru}(\mathrm{bpy})_{3}\right]^{2+}$ was utilized as the reference molecule. ${ }^{2,3}$ The quantum yields of the probe were calculated according to the following formula,

$$
\Phi_{S}=\Phi_{R} \frac{A_{R} I_{S}}{A_{S} I_{R}}
$$

In which, $\Phi$ stands for the quantum yield, $I$ represents the fluorescence intensity, $A$ represents the absorbance intensity, and the subscript " $S$ " stands for sample and " $R$ " stands for reference, respectively.

\section{Cell viability assay}

The cytotoxicity of Ir-BPDA was evaluated in RAW 264.7 cells by MTT assay. At 2-3 days after seeding, thecells were counted by hemocytometer and seeded into a 96-well cell-culture plate at a cell densityof $1 \times 10^{4}$ cells per well and then incubated for $24 \mathrm{~h}$ at $37{ }^{\circ} \mathrm{C}$ under $5 \% \mathrm{CO}_{2}$ in a $\mathrm{CO}_{2}$ incubator (HERA cell 150i, Thermo Scientific). The complex was thenadded at indicated concentrations to quadruplicate wells for different hours. Then the medium was replacedwith fresh DMEM medium and MTT was added to each well at a final volume of $5 \mathrm{mg} \mathrm{mL}^{-1}$. The microplates were incubated at $37{ }^{\circ} \mathrm{C}$ for $4 \mathrm{~h}$. The medium was then removed and $150 \mu \mathrm{L}$ of DMSO solution was added to the plates and shaken to dissolve the formazan products. The absorbance of the samples was measured at the $595 \mathrm{~nm}$ using an ELISA reader (BioTek Instruments, Winooski, VT) The cell survival rate in the control wells without Ir-BPDA solutions was considered as $100 \%$ cell survival with a Becher \& Hickl (BH) time-correlated single photon counting (TCSPC) system. The PLIM data of Ir-BPDA from RAW 264.7 cells and zebrafish were collected by SPC Image software (Becker \& Hickl GmbH, the bh TCSPC Handbook sixth Edition).

\section{ICP-MS assay}

In ICP-MS experiment, RAW 264.7 cells (ca. $1.5 \times 106$ cells) were incubated with $10 \mu \mathrm{M}$ Ir-BPDA complexes $\left(0.5 \%\right.$ DMSO, v\%) for $30 \mathrm{~min}$ at $37{ }^{\circ} \mathrm{C}$, respectively. After washing, trypsinization and counting, RAW 264.7 cells were equally divided into for parts for the determination of iridium content in nuclei, cytoplasm, mitochondria, lysosomes. All extractants were digested by $60 \%$ nitric acid at room temperature for at least $24 \mathrm{~h}$. And subsequently processed by the aforementioned method. 


\section{Supporting Figures and tables}

MS Spectrum Graph

Peak\#:1 Ret.Time:Averaged 0.900-0.934(Scan\#:55-57)

$\begin{array}{ll}\text { BG Mode:Calc } 0.800<->1.184(49<->72) & \\ \text { Mass Peaks:551 Base Peak:310.95(4753755) Polarity:Pos Segment1 - Event1 }\end{array}$

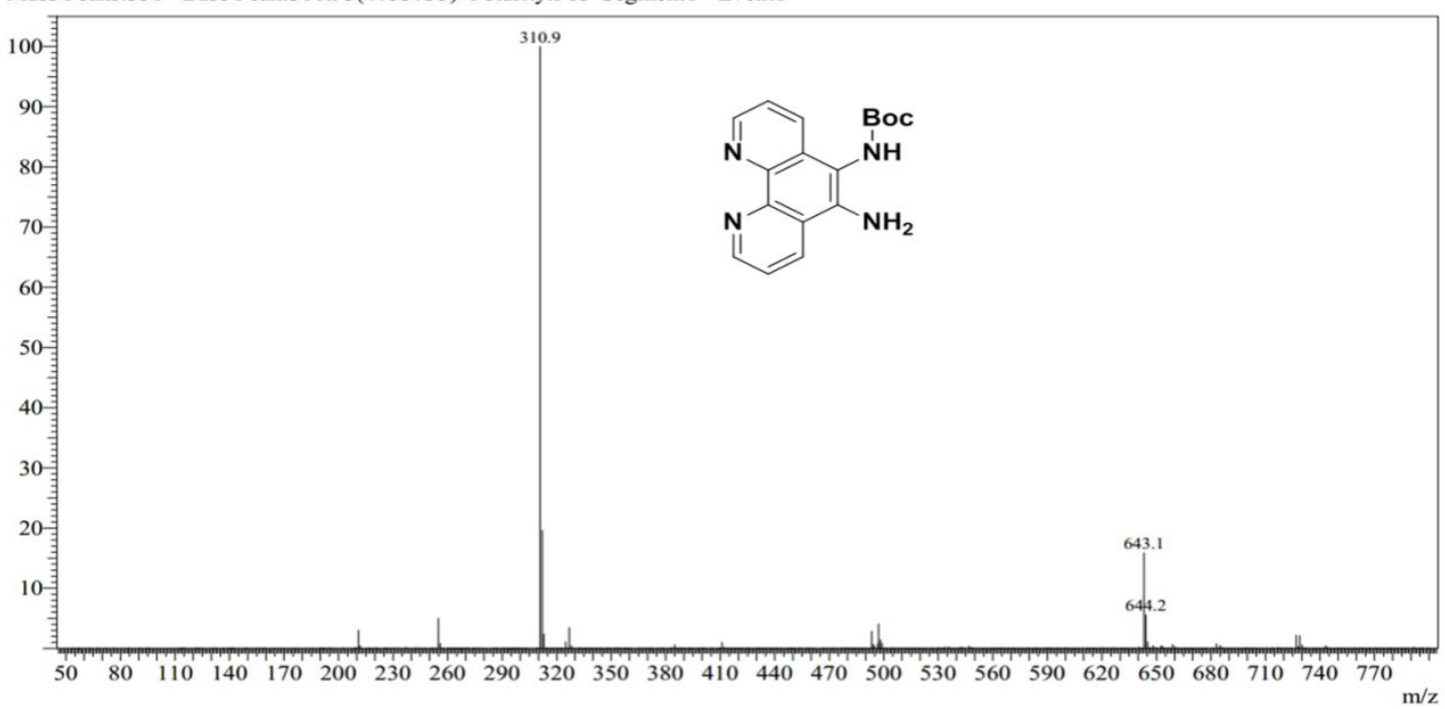

थै

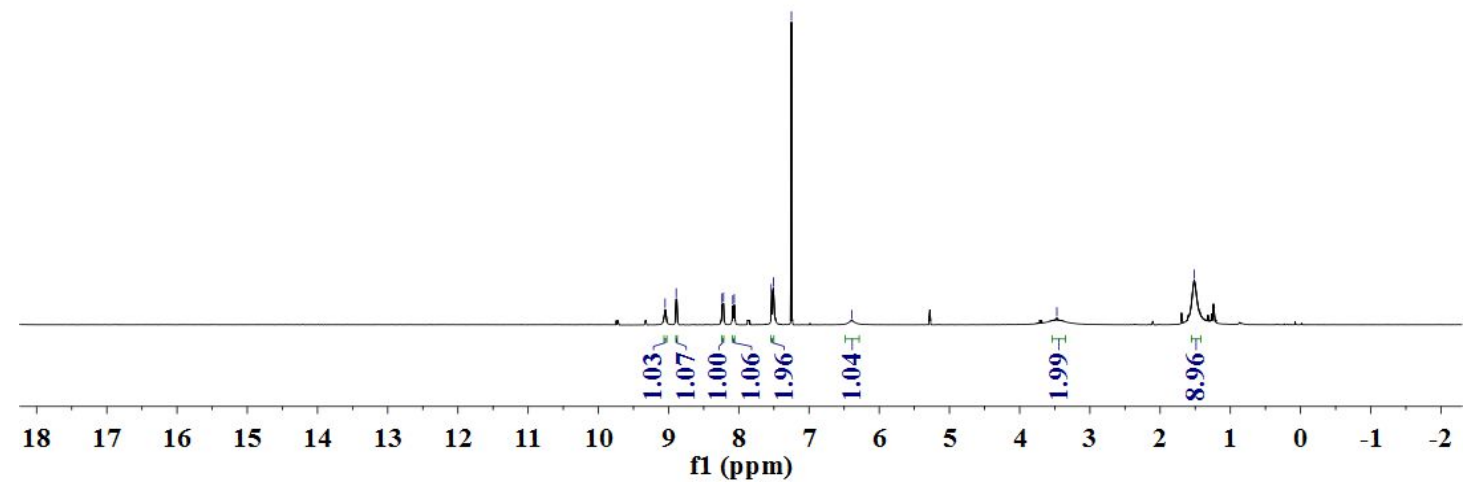

Figure S1. ESI-MS and ${ }^{1} \mathrm{H}$ NMR spectra of compound 1. 
MS Spectrum Graph

Peak\#:1 Ret.Time:Averaged 2.083-2.117(Scan\#:126-128)

Mass Peaks:669 Base Peak:823.15(9089438) Polarity:Pos Segment1 - Event1

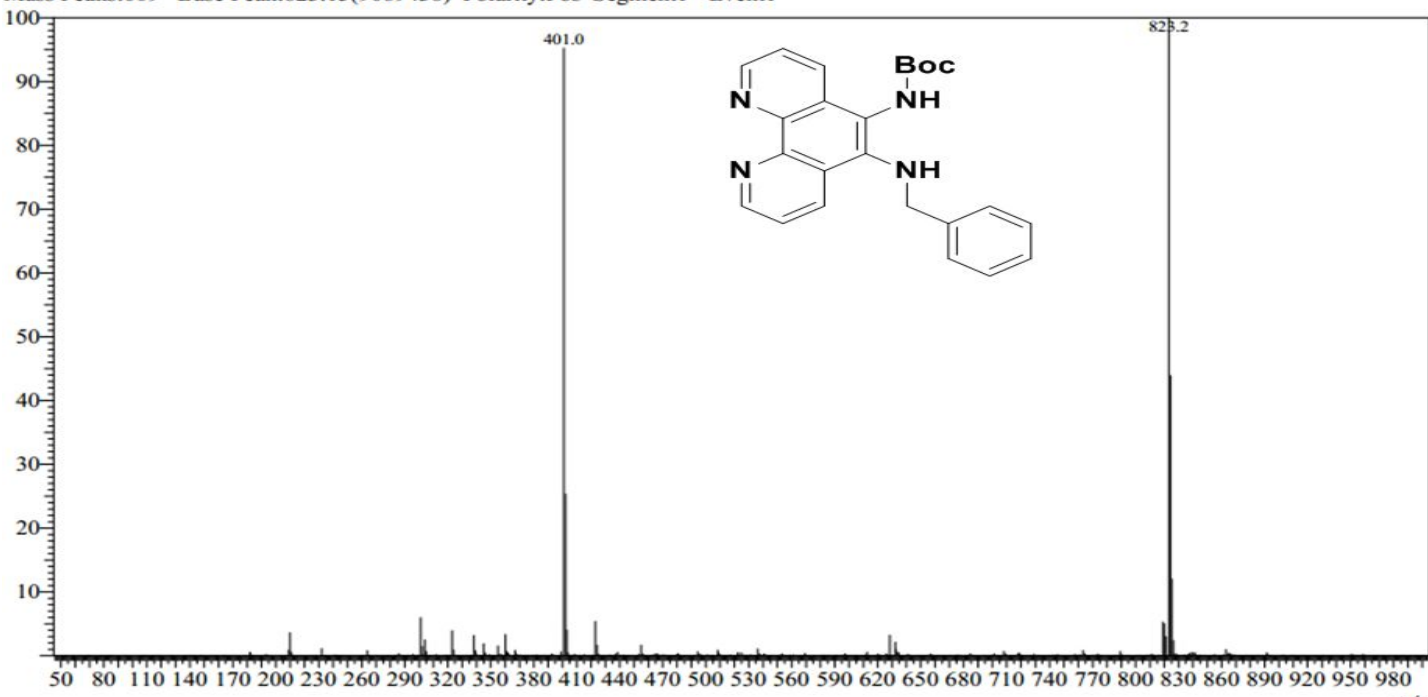

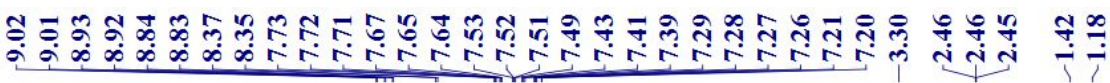

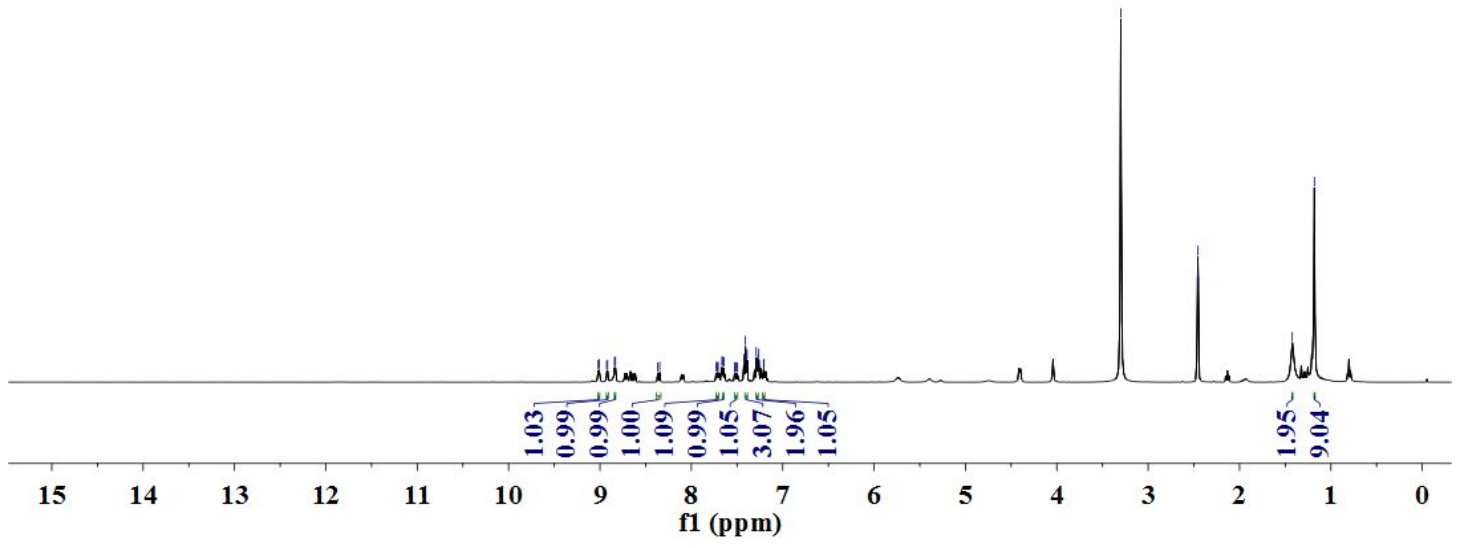

Figure S2. ESI-MS and ${ }^{1} \mathrm{H}$ NMR spectra of compound 2. 
MS Spectrum Graph

Peakili:1 Ret.Time:Averaged 0.750-0.783(Scant:46-48)

Mass Peaks 489 Base Peak-301.00(7852746) Polarity:Pos Segment1 - Event1

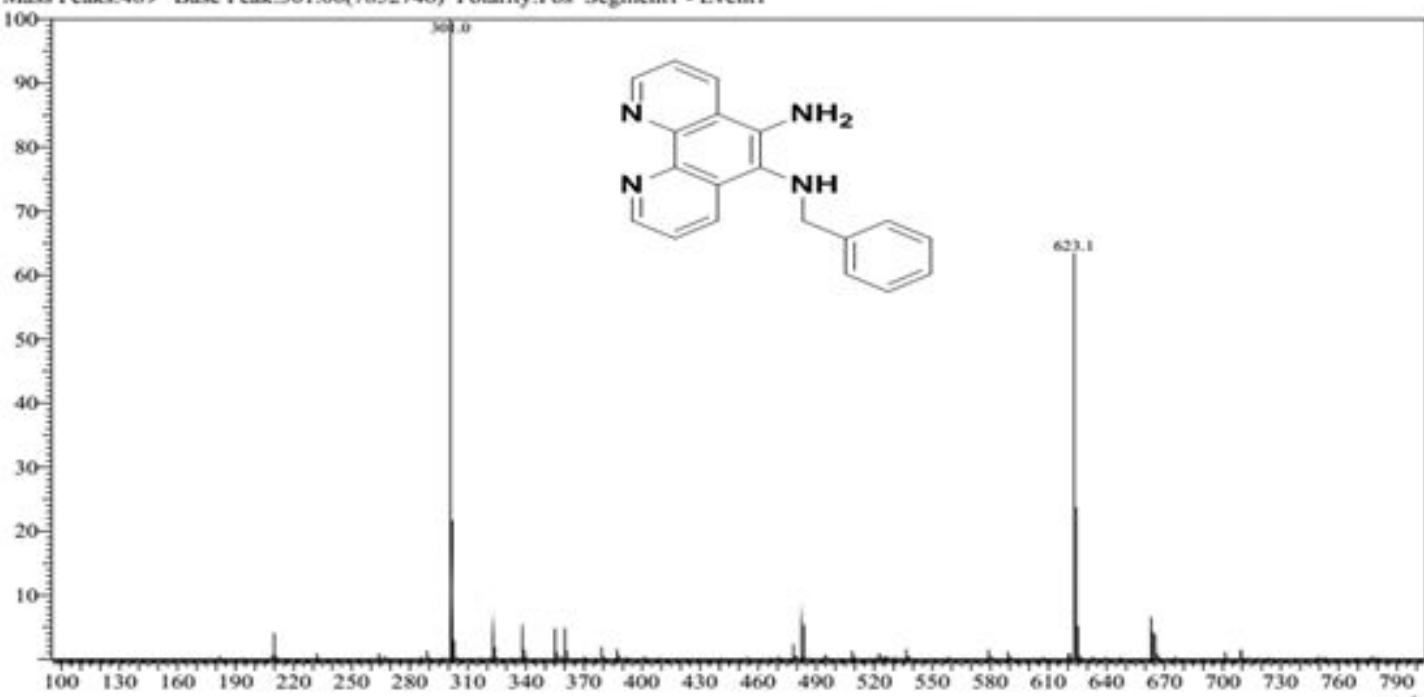

$100130160190 \quad 220 \quad 250 \quad 280 \quad 310 \quad 340 \quad 370 \quad 400 \quad 430 \quad 460 \quad 490 \quad 520 \quad 550 \quad 580 \quad 610 \quad 640 \quad 670 \quad 700 \quad 730 \quad 760 \quad 790$

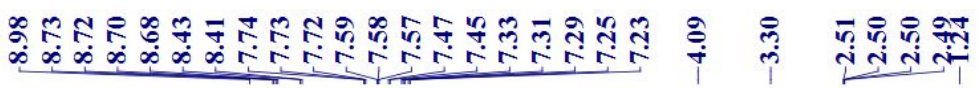

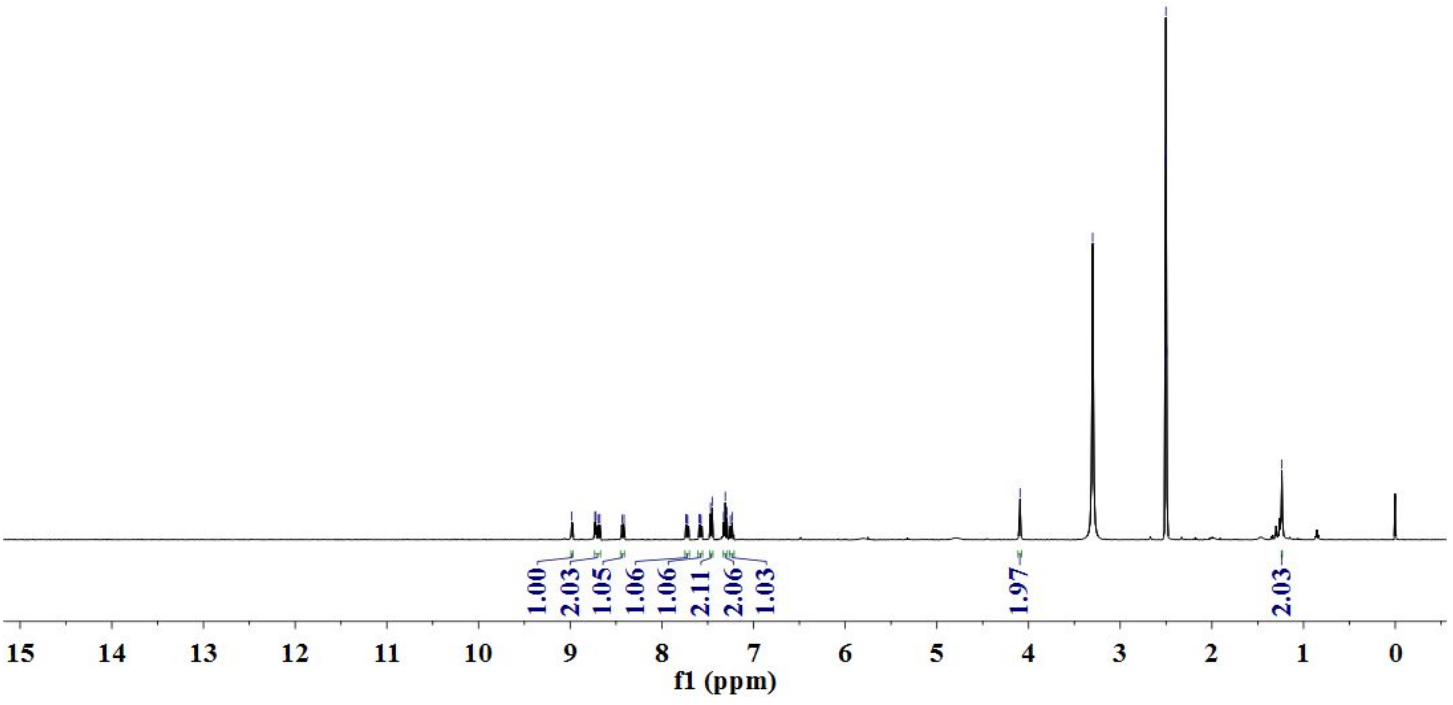

Figure S3. ESI-MS and ${ }^{1} \mathrm{H}$ NMR spectra of compound 3. 
Peak\#:1 Ret.Time:Averaged 2.867-2.900(Scan\#:173-175)

Mass Peaks: 1004 Base Peak:499.95(9804218) Polarity:Pos Segment1 - Event 1

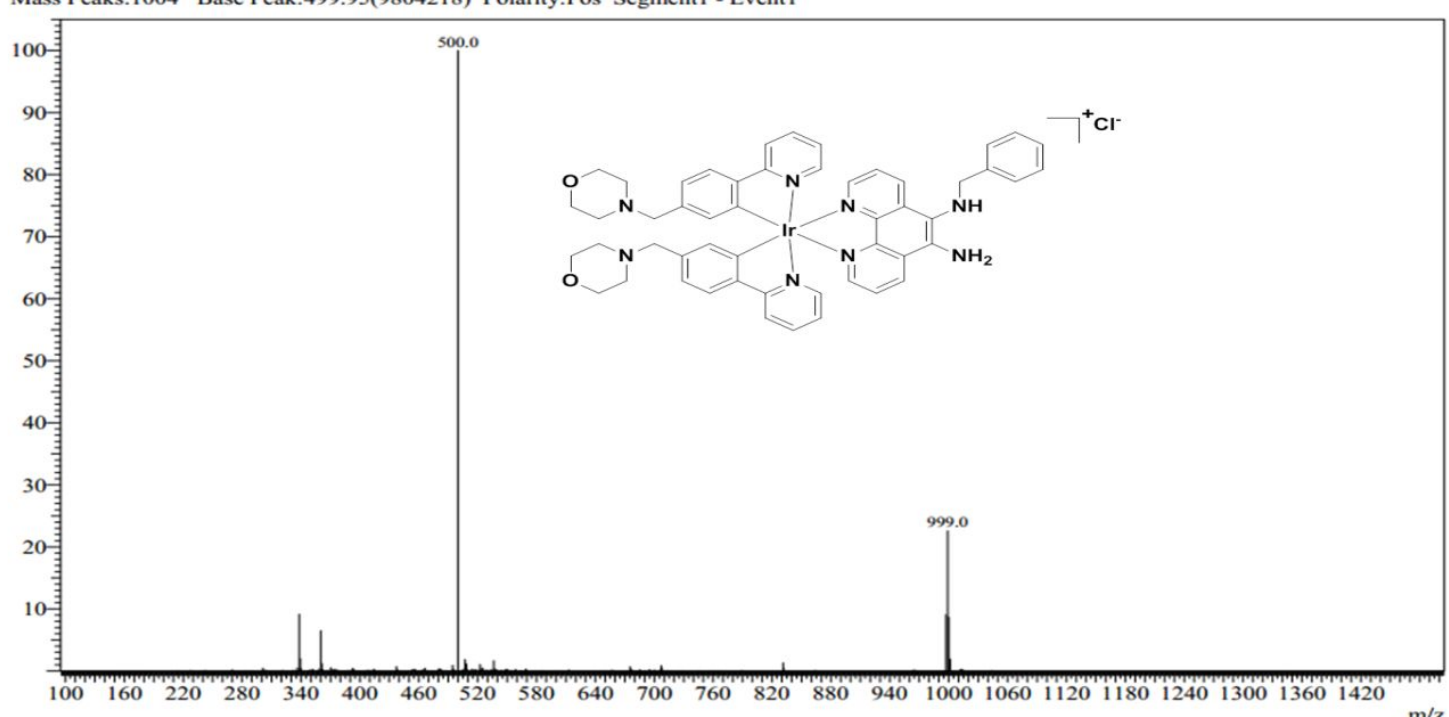

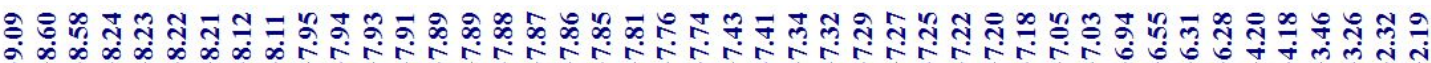

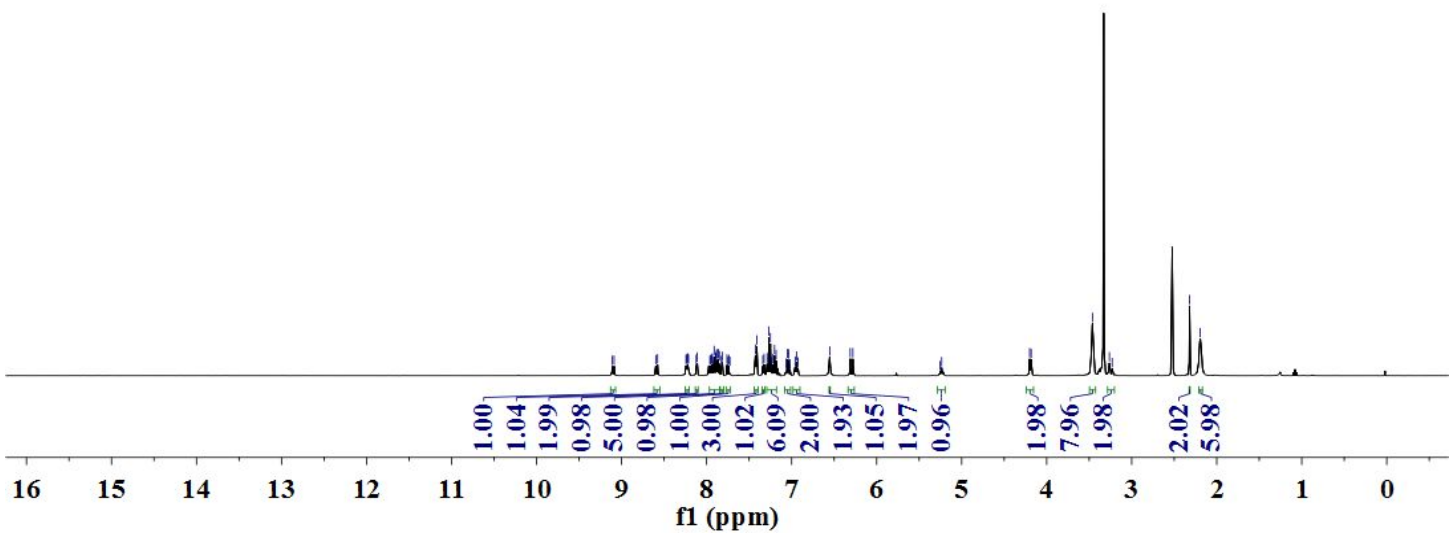

Figure S4. ESI-MS and ${ }^{1} \mathrm{H}$ NMR spectra of Ir-BPDA. 


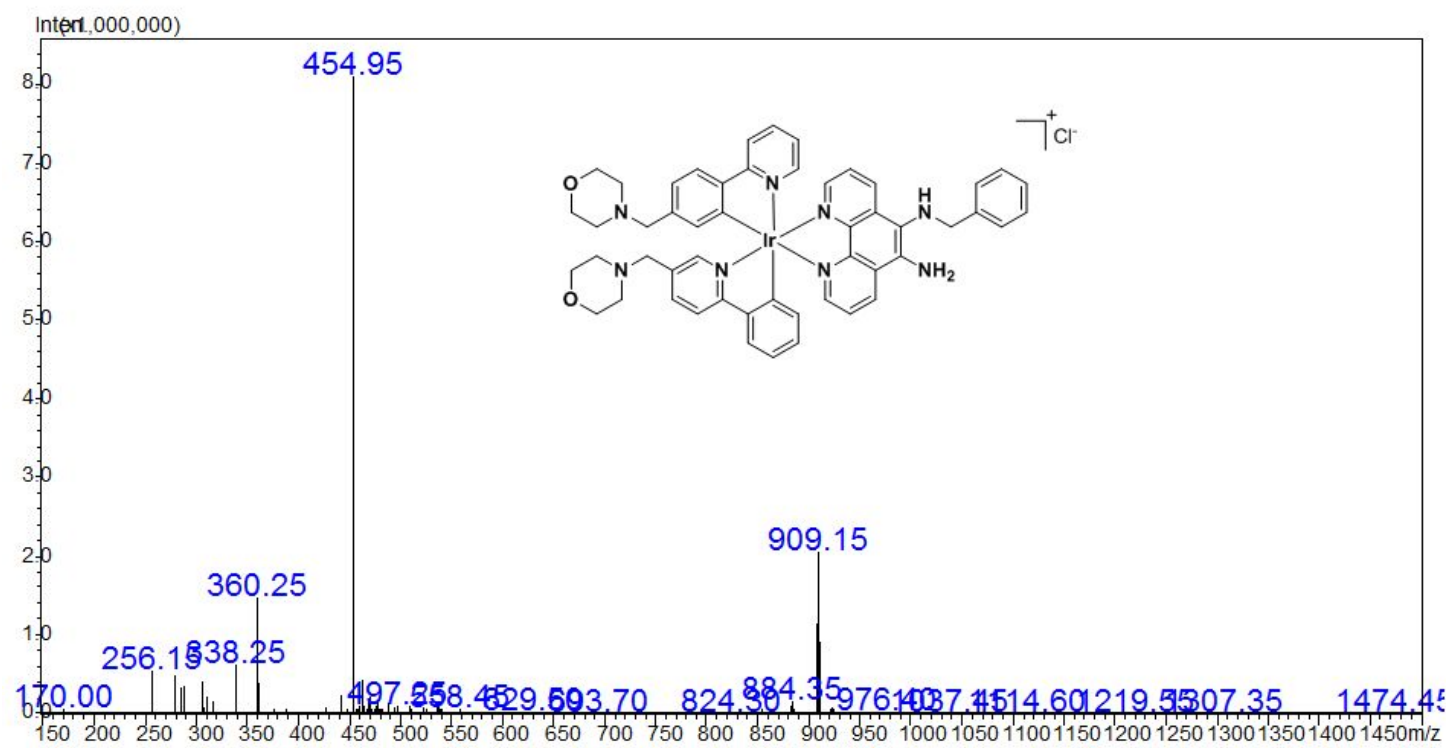

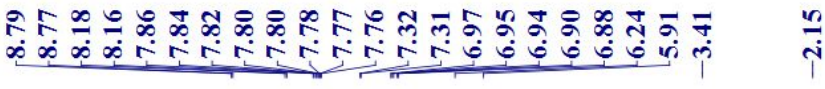

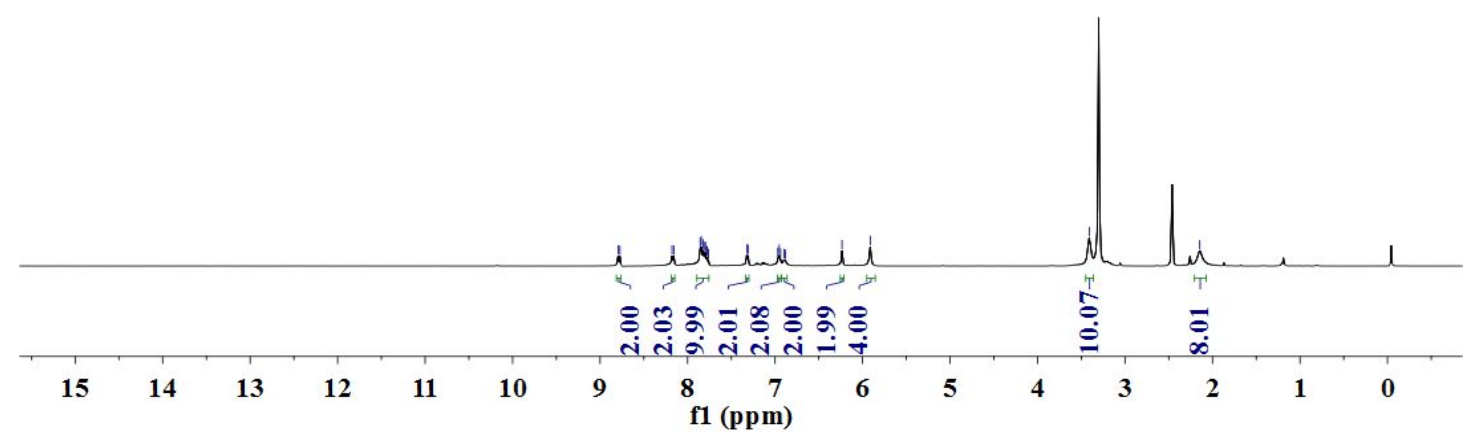

Figure S5. ESI-MS and ${ }^{1} \mathrm{H}$ NMR spectra of Ir-PDA. 

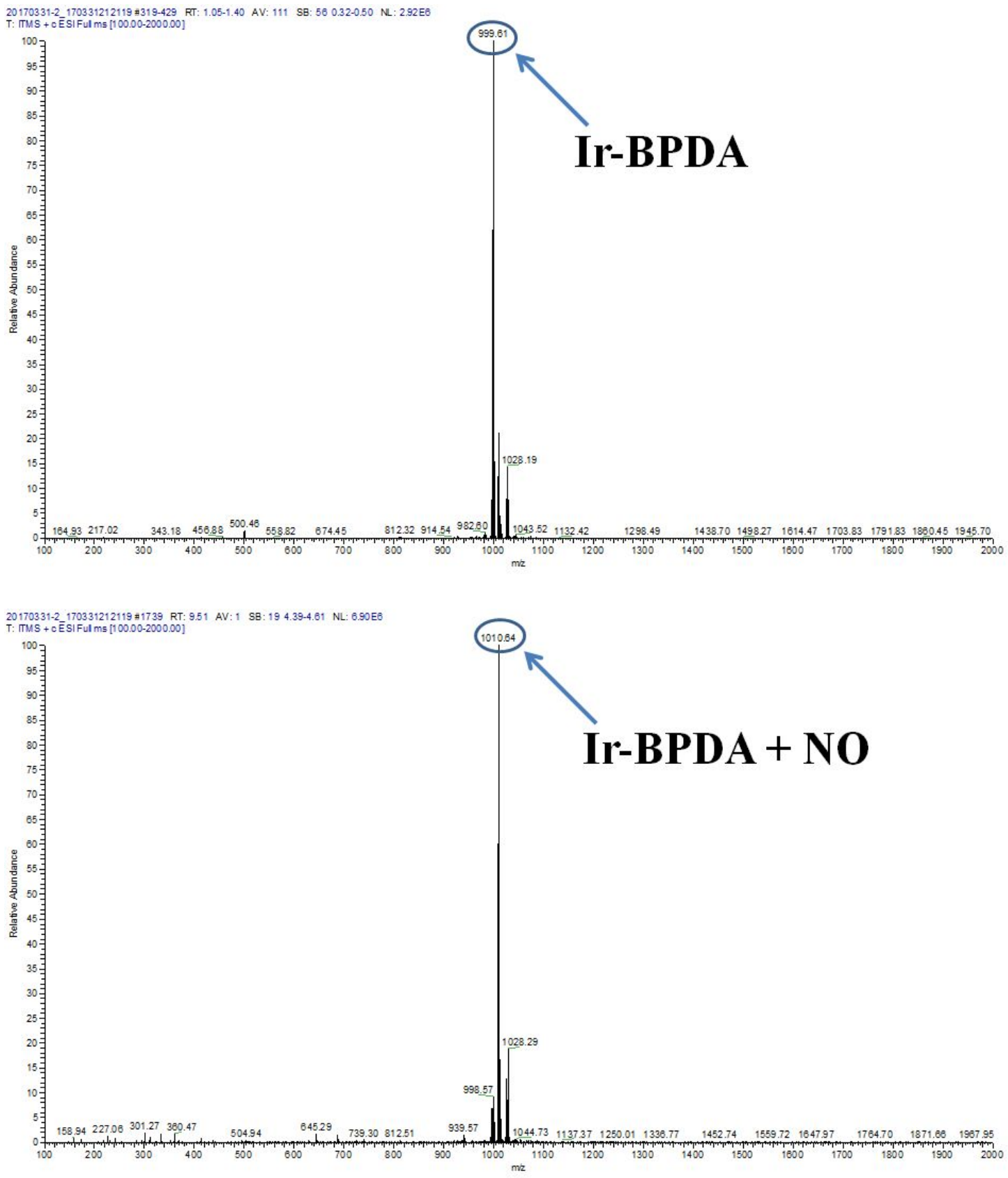

Figure S6. Mass spectra of the product of Ir-BPDA reacted with 10 eq. NO in PBS buffer of pH 7.4 . 

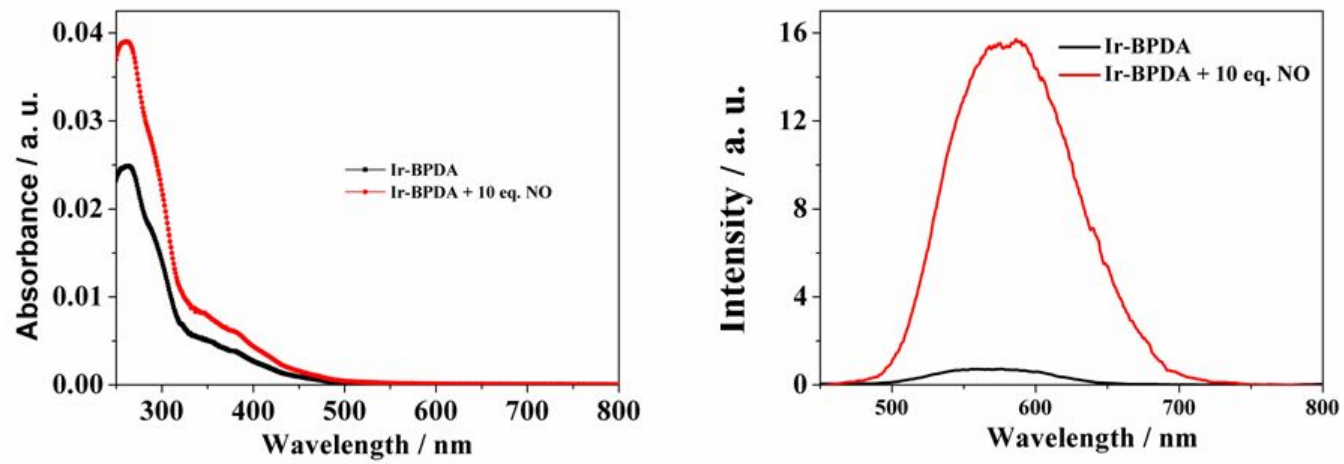

Figure S7. The absorption (left) and phosphorescent (right) spectra of $1 \mu \mathrm{M}$ Ir-BPDA before and after reaction with NO in the PBS buffer.

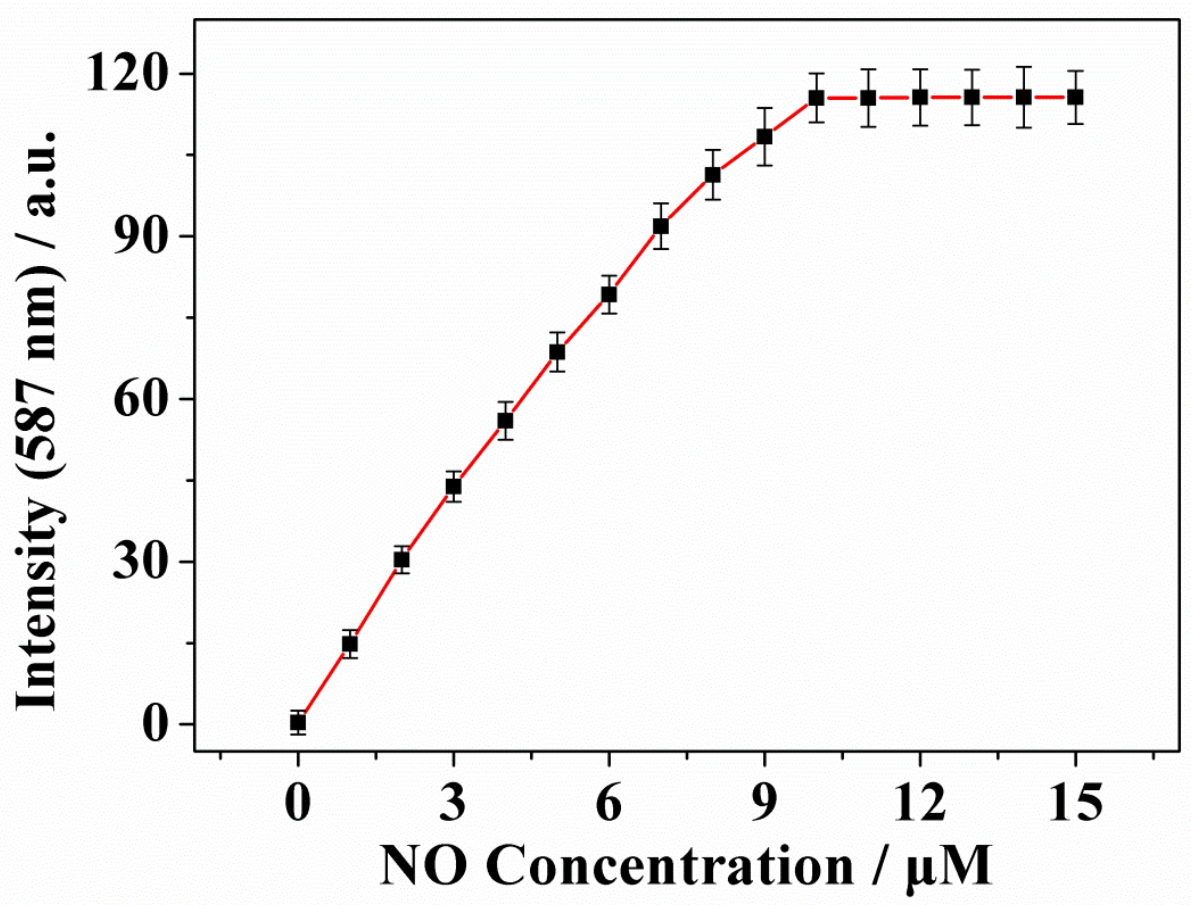

Figure S8. Determination of detection limit based on fluorescence response of low-micromolar NO toward $10 \mu \mathrm{M}$ Ir-BPDA at $37^{\circ} \mathrm{C}$ for $10 \mathrm{~min}$ in PBS buffer (pH 7.4). The detection limit is determined to be $77.2 \mathrm{nM}$ by using $3 \sigma / \mathrm{k}$ method. $\lambda_{\mathrm{ex}}=405 \mathrm{~nm}$. Slits: $5 / 5 \mathrm{~nm}$. 

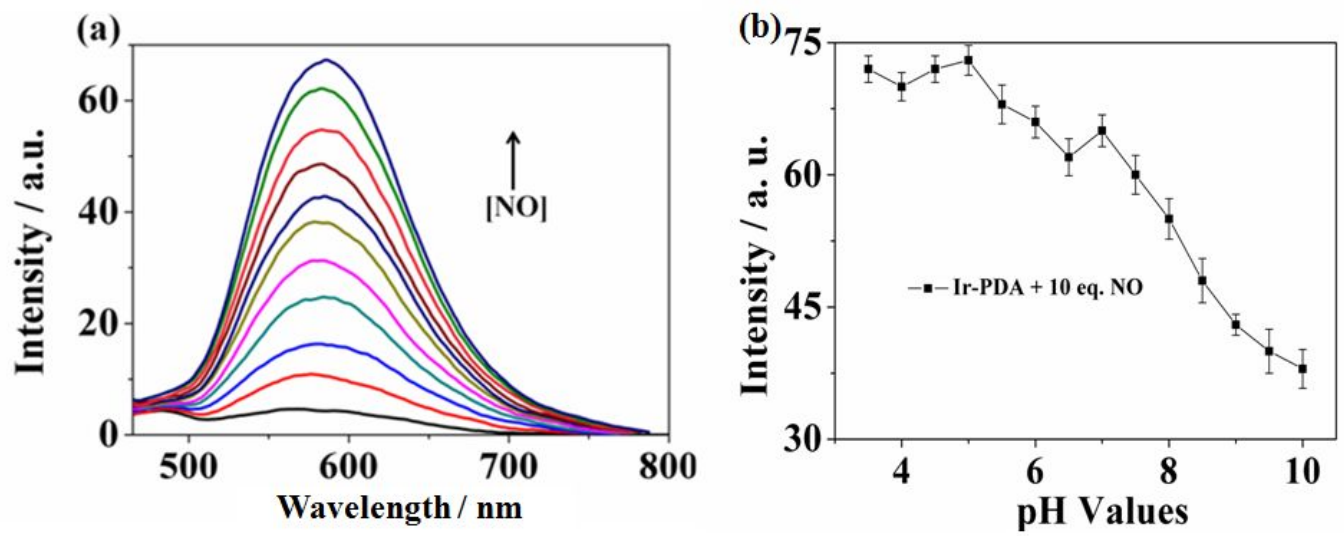

Figure S9. (a) Emission spectra of Ir-PDA $(10 \mu \mathrm{M})$ upon addition of increasing concentrations $(0-10 \mu \mathrm{M}) \mathrm{NO}$ in PBS (containing 10\% DMSO, $\mathrm{pH}=7.4)$ solution. (b) Phosphorescence intensity at $575 \mathrm{~nm}$ of Ir-PDA $(10 \mu \mathrm{M})$ under different $\mathrm{pH}$ values in the presence of 10 equiv. of NO in PBS buffer. $\lambda_{\mathrm{ex}}=405 \mathrm{~nm}$. Slits: $5 / 5 \mathrm{~nm}$.
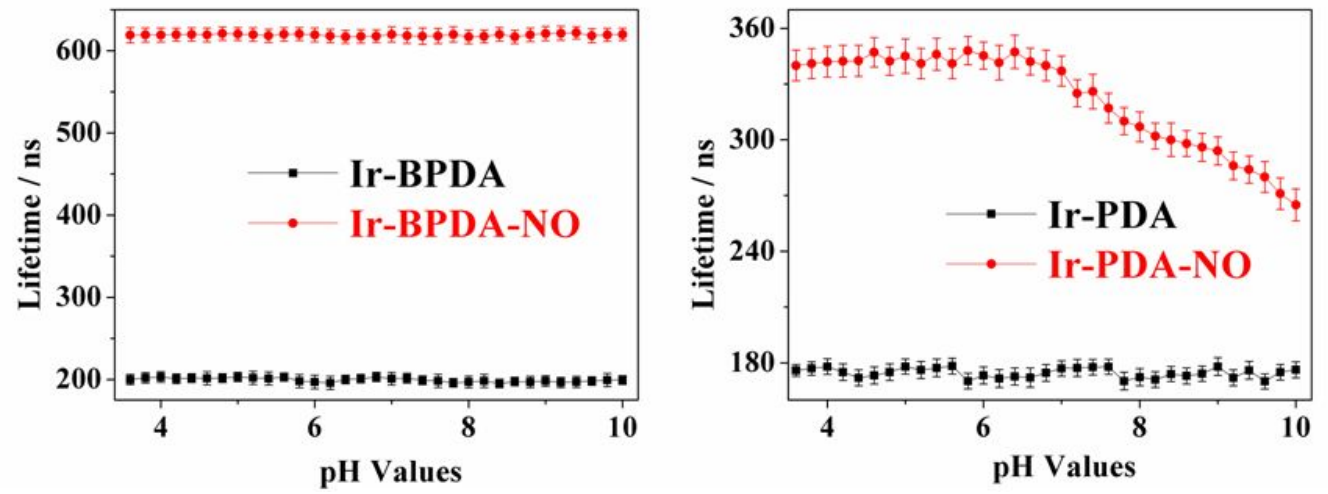

Figure S10. Phosphorescence lifetime of Ir-BPDA and Ir-PDA under different $\mathrm{pH}$ values in the absence and presence of 10 equiv. of NO in buffer solution. $\lambda_{\mathrm{ex}}=405 \mathrm{~nm}$. Slits: $5 / 5 \mathrm{~nm}$. 


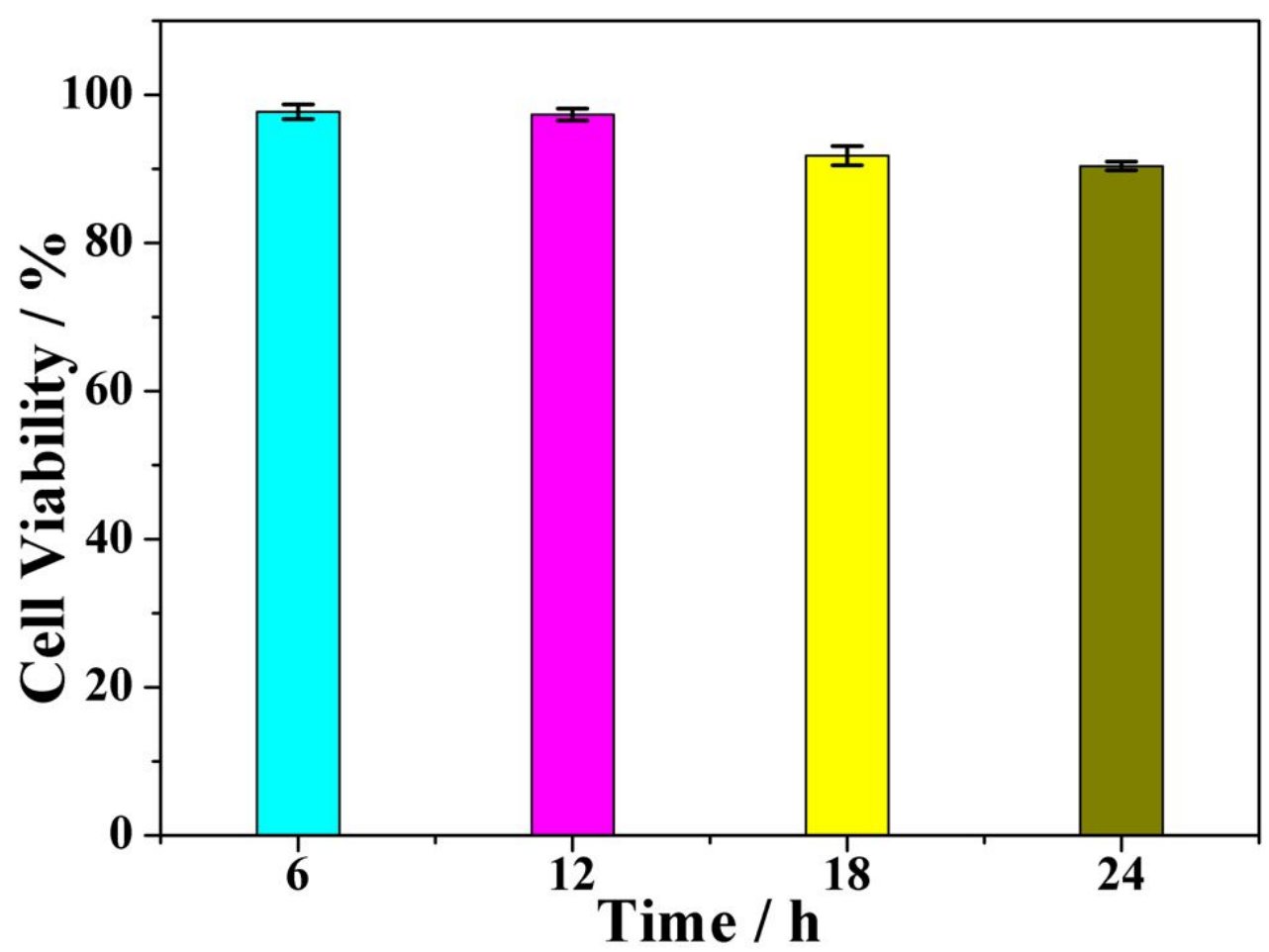

Figure S11. Percentage of viable RAW 264.7 cells after treated with Ir-BPDA $(10 \mu \mathrm{M})$ for increasing hours.

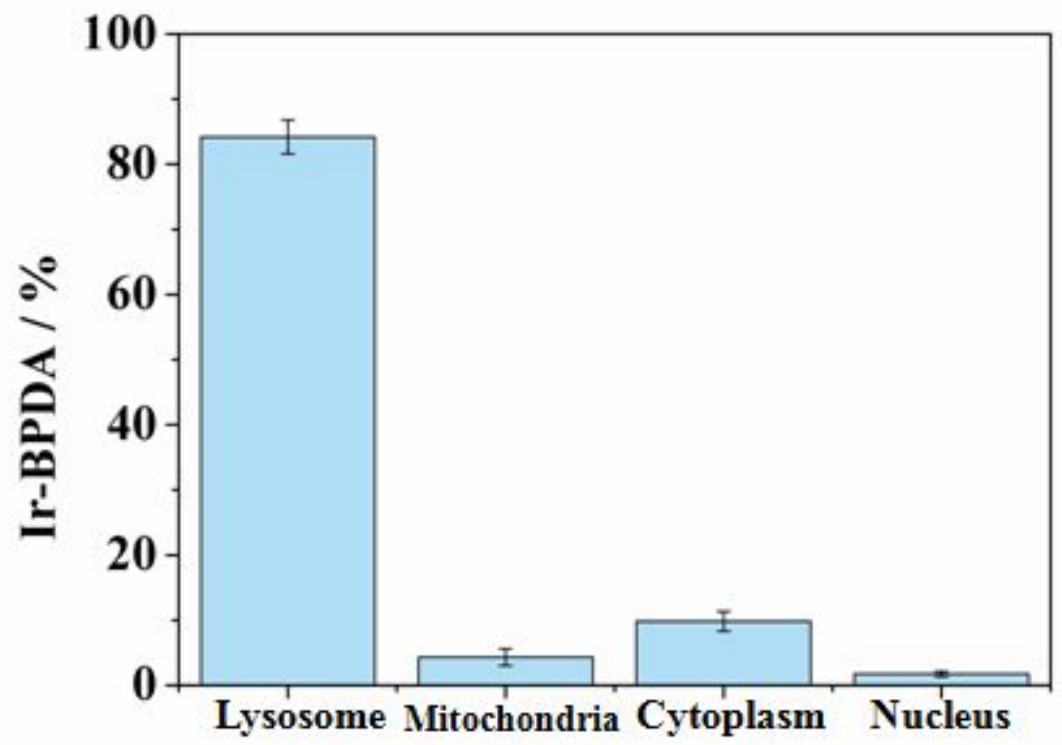

Figure S12. Percentage of distribution in RAW 264.7 cells after treated with Ir-BPDA (Cytoplasm does not include Lysosome and Mitochonria in it). 


\section{Reference}

1. Yuan, L.; Wang, L. Agrawalla, B. K.; Park, S. J.; Zhu, H.; Sivaraman, B.; Peng, J.; Xu, Q.; Chang, Y. Development of Targetable Two-Photon Fluorescent Probes to Image Hypochlorous Acid in Mitochondria and Lysosome in Live Cell and Inflamed Mouse Model. J. Am. Chem. Soc. 2015, 137, 5930-5938.

2. Van, J.; Watts, R. J. Temperature dependence of the photophysical and photochemical properties of the tris(2,2'-bipyridyl)ruthenium(II) ion in aqueous solution. J. Am. Chem. Soc. 1976, 98, 4853-4858.

3. Kober, E. M.; Caspar, J. V.; Lumpkin, R. S.; Meyer, T. J. Application of the energy gap law to excited-state decay of osmium(II)-polypyridine complexes: calculation of relative nonradiative decay rates from emission spectral profiles. J. Phys. Chem. 1986, 90, 3722-3734. 